\title{
School Curriculum and HIV/AIDS: A Study of District Swat
}

\author{
I. Ullah (Ihsan-U-Ullah)', A. Naz (Arab Naz)2, T. Khan(Tariq Khan)3, S. Khan (Sarfraz \\ Khan) ${ }^{4}$, A. Gul (Ayesha Gul)5, W. Khan (Wassem Khan)6, N. Khan (Nasar Khan)7
}

${ }^{1}$ PHD Scholar, Department of Sociology University of Malakand,

Original Article Khyber Pakhtunkhwa, Pakistan

2 Professor Department of Sociology, University of Malakand, Khyber Pakhtunkhwa Pakistan

${ }^{3}$ Assistant Professor Department of English University of Malakand Khyber Pakhtunkhwa, Pakistan

${ }^{4}$ Assistant Professor Sociology, QAU Islamabad, Pakistan

${ }^{5}$ Department of Social Work, SBKWU University Baluchistan, Pakistan

${ }^{6}$ Lecturer Sociology University of Malakand, Khyber Pakhtunkhwa Pakistan

${ }^{7}$ Lecturer Sociology University of Chitral Pakistan

\section{E-mail address:}

arab_naz@yahoo.com

\section{Reprint address:}

Ihsan-U-Ullah

Department of Sociology

University of Malakand

Khyber Pakhtunkhwa

Pakistan

Source: Clinical Social Work and Health Intervention

Volume: 10

Issue: 1

Pages: $11-22$

Cited references: 13

\section{Reviewers:}

Steve Szydlowski

University of Scranton School of Education, USA

Victor Namulanda Wanjala

Catholic university of Eastern Africa, Nairobi, Kenya

\section{Key words:}

District Swat. HIV. AIDS. School Curriculum Contents. School Students. Transmission. Preventive Measures. Unawareness.

\section{Publisher:}

International Society of Applied Preventive Medicine i-gap

CSWHI 2019; 10(1): 11 - 22; DOI 10.22359/cswhi_10_1_02 @ 2019 Clinical Social Work and Health Intervention 


\section{Abstract:}

This study was performed in District Swat Khyber Pakhtunkhwa Pakistan. It aimed to underline the problem of school level health education and specifically the insufficiency of contents related to HIV (Human Immune Virus)/AIDS (Acquired Immune Deficiency Syndrome) in the curriculum taught at school resulting in unawareness of students concerning basic information on HIV/AIDS. This study is both qualitative and quantitative in nature whereas simple random sampling (SRS) and proportional allocation method were used for selection of samples. Textual analysis of school books was carried out to note down the relevant general information (sufficiency and deficiency) with reference to HIV/ AIDS. A textual analysis of selected 8 books of grades 9 and 10 was conducted to interpret the presence of textbook matter discussing HIV/ AIDS in current school books. Results of the data analysis proved that school syllabus and books are incomplete in respect to the contents for awareness on HIV/AIDS. In addition, a total of 150 respondents were selected from grades 9 and 10, students of male government schools of the area and data regarding HIV awareness was collected through questionnaire. Most of the respondents were found to be unfamiliar with prevention and mode of transmission of HIV/ AID.

\section{Introduction}

All over the world, young people are at the center of the HIV epidemic; almost half of all HIV-infected public are aged 15-24 years (Monasch \& Mahy, 2006). In 2007, Southeast Asia and the Pacific region have the succeeding highest prevalence of HIV with an estimated 1.27 million young people living with HIV (United Nations Population Fund, HIV/AIDS Branch, 2008.). Many reasons increase the vulnerability of young people to HIV but lack of awareness has been identified as one of the leading factors (Anderson, Kann, Holtzman, Arday, Truman \& Kolbe, 1990). Whereas many channels are present through which information can be offered to young people (Kirby, Laris, \& Rolleri, 2005), interventions through the education sector have been implemented throughout the world to contact a large number of young people easily (Thomson, Currie, Todd \& Elton, 1990).

HIV/AIDS, reproductive health and sexuality are multifaceted and controversial subjects that teachers and schools may be reluctant to tackle (Oshi, Nakalema, and Oshi, 2005). Curriculum designers need to prepare adequate syllabuses and distribute those to schools so as to guide teachers on what to teach and how. The syllabuses need to be graded according to grades (Paul, 2012). Over the last decade, there has been increased support for the teaching of life skills to young people, partly due to the perceived limitations of information-based HIV/AIDS education (Boler \& Aggleton, 2004).

Dealing with young people is a longterm investment. Young people are a force for change, and it is vital to implement protected behavior patterns before they become sexually active. The school system is the single social structure with the potential to 
reach all of these young people (UNESCO, 2002). Young people are at the center of the HIV/AIDS epidemic. Their behavior; the degree to which their rights are protected; the services and information they receive can help to determine the quality of life of millions of people. Young people are particularly vulnerable to HIV infection and they may also carry the burden of caring for family members living with HIV/AIDS. Around the world, AIDS is shattering young people's opportunities for healthy adult lives. Nevertheless, it is young people who offer the greatest hope for changing the course of the epidemic (UNAIDS, 2001).

Schools are key locations for health promotion and shaping children's minds from an early age. The input of health promotion to the health and well-being of students has been increasingly and widely acknowledged. On the other hand, the progress of suitable approaches for evaluating health promotion in schools is still a major topic of conversation (Pommier, Guevel \& Jourdan, 2010). Children spend most of their day in school and it is one of the most noteworthy communities they belong to apart from their family. It is now acknowledged that school plays an important role by providing protection and support for children affected by HIV and AIDS (Ishikawaa, Pridmoreb, Carr- Hillb \& Chaimuangdee, 2011).

Curriculum-based education can add to providing what young people need in a structured format, with flexible approaches that can be executed in a variety of situations. With these features, curriculum-based approaches comprise an important strategy in addressing HIV/AIDS and unintended pregnancy. Program evaluations and overview studies have found that curriculum-based HIV education can be effective in widely differing geographic areas; various cultural settings; among youth of different income levels; and both sexes (Kirby, Laris \& Rolleri, 2005).

Considering Pakistani society, it is researcher's observation that a matriculate school boy/girl is not capable even to define HIV/AIDS. After school life this deficiency leads the individual to carry out various preventable mistakes. Comparing this scenario of our country with the external world it is evident that every person in the community must know some of the very vital health related concepts theoretically as well as practically concerning this disease. Some of the key areas are preventive health measures like safe use of needles; careful blood receiving and donating; protective sexual behavior; etc.

Although literacy rate of District Swat is higher as compared to other districts, the school syllabus is limited concerning health contents leading to deficient health education and hence health problems in the area. The major increase in the communicable and non-communicable diseases in this area witnesses the low level of health awareness among the literate as well as illiterate populations. This study helps to analyze the fundamental gaps in school syllabus and the degree of importance given to the issue of infectious diseases like HIV/ AIDS. This study highlights the deficiency in school curriculum regarding contents on HIV/AIDS as well as the unawareness of students about this disease.

\section{Objective of the Study}

This study has been designed to analyze the contents in school syllabi regarding the information and text for HIV/AIDS and other related diseases. The intention is to also analyze the efficacy of the syllabi in promoting awareness among students regarding such diseases or their causes. 


\section{Hypothesis}

Insufficient HIV/AIDS related contents in school curriculum leads to unawareness in students.

\section{Materials and Methods}

\section{Content Analysis of School Textbooks}

During the process of inquiry four of the vital subjects of grades 9 and 10 i.e. Biology, General Science, Health and Physical (table-1). The female primary, middle, high and higher secondary schools are 429, 48, 20 and 04 respectively (Elementary \& Secondary Education Department, Govt. of NWFP, 2008). As the researcher could not cover the whole area therefore it was limited to the government high and secondary schools situated inside Mingora city. Due to the problem of accessibility the study was further limited to boy's schools only and the girls' schools were excluded.

Table 1: Number of Functional Govt. Schools, Enrollment and Working Teachers in Swat 2007-08 There are 8 High Schools (male) in Mingora city, 50 \% (04 Schools) were selected through Simple Random Sampling (SRS). These schools were G.H.S.S. Amankot, G.H.S No. 3 Shah Dara, G.H.S No. 4 Mulla Baba and G.H.S Nawaykaly represented by S1, S2, S3 and S4 respectively.

\begin{tabular}{|r|r|r|r|r|r|r|r|r|r|r|r|r|}
\hline \multirow{2}{*}{ Gender } & \multicolumn{3}{|c|}{ Primary } & \multicolumn{3}{c|}{ Middle } & \multicolumn{3}{c|}{ High } & \multicolumn{3}{c|}{ Higher/Secondary } \\
\cline { 2 - 14 } & School & Enrol. & $\begin{array}{l}\text { Working } \\
\text { Teacher }\end{array}$ & School & Enrol. & $\begin{array}{l}\text { Working } \\
\text { Teacher }\end{array}$ & Schools & Enrol. & $\begin{array}{l}\text { Working } \\
\text { Teacher }\end{array}$ & Schools & Enrol. & $\begin{array}{l}\text { Working } \\
\text { Teacher }\end{array}$ \\
\hline BOYS & 841 & 133598 & 3033 & 84 & 8325 & 618 & 67 & 21242 & 1080 & 13 & 8704 & 397 \\
\hline GIRLS & 429 & 67606 & 1580 & 48 & 3675 & 273 & 20 & 9288 & 255 & 4 & 3679 & 74 \\
\hline TOTAL & 1270 & 201204 & 4613 & 132 & 12000 & 891 & 87 & 30530 & 1335 & 17 & 12383 & 471 \\
\hline
\end{tabular}

Source: Annual Statistical Report 2007-08, District Swat: EMIS Elementary \& Secondary Education Department, Govt. of NWFP

Education and Islamic Education were selected purposively for content analysis regarding HIV/AIDS. The contents of these books have thoroughly analyzed and the list of the contents has been given at the end of the paper.
Total number of students in grades 9 and 10 in the selected 4 schools gave the target population of 547. As each school has different numbers of students, samples were selected through William Lawrence Neuman Formula of Proportional Allocation Method (Neuman, 2000) which is given as

$$
\text { Stratum Sample Size }=n=\frac{\text { Population of the Stratum }}{\text { Total Population of the Strata }} \times \text { Sample Size }
$$

\section{Sampling Technique}

In district Swat the number of male primary, middle, high and higher secondary schools are 841, 84, 67 and 13 respectively 


\section{Sample Frame}

Now representing target population i.e. 547 by "N", the selected sample size i.e. 150 by " $n$ " and the selected schools with $\mathrm{S} 1, \mathrm{~S} 2$, $\mathrm{S} 3$ and S4 and their population is 169, 239, 73 , and 66 respectively then using Proportional Allocation Method the sample size of stratum $n 1$ will be calculated as under:

\section{Biology for Grades 9 \& 10:}

It is the main subject taught to the students of science in grades 9 and 10 containing some information regarding human anatomy and physiology. This book has a total of 18 chapters in which nine chapters are taught in grade 9 while the other half are taught in grade 10 . The contents included in

G.H.S.S. Amankot $=n_{1}=\frac{S_{1}}{S} \times 150$, by putting values $169 / 547 \times 150=46$

Similarly by calculating all the strata the following sample frame is obtained.

\begin{tabular}{|l|l|c|l|l|}
\hline School Name & Denoted by & Strata & Population & Sample Size \\
\hline G.H.S.S Amankot & S1 & $\mathrm{n} 1$ & 169 & 46 \\
\hline G.H.S No. 3 Shah Dara & S2 & $\mathrm{n} 2$ & 239 & 66 \\
\hline G.H.S No. 4 Mulla Baba & $\mathrm{S} 3$ & $\mathrm{n} 3$ & 73 & 20 \\
\hline G.H.S Nawaykaly & $\mathrm{S} 4$ & $\mathrm{n} 4$ & 66 & 18 \\
\hline TOTAL & $\mathrm{S}$ & $\mathrm{N}$ & 547 & 150 \\
\hline
\end{tabular}

\section{Tool of Data Collection}

In this study a structured questionnaire was used for data collection.

\section{Data Analysis}

The collected data is analyzed through SPSS (Statistical Package for Social Science) software (16th version).

\section{Results \& Discussion}

\section{Part-l: Content Analysis of School Text Books with respect to HIV/AIDS Contents}

Keeping in view the main theme of HIV/ AIDS, the researchers of the current study selected school level textbooks for analysis. As the field data is collected from the students of grades 9 and 10 therefore the selection of books for analysis was also delimited to a total of 4 books from both these classes. The books included Biology, General Science, Islamic Study (compulsory) and Health \& Physical Education (grades 9 and 10). this course are majorly concerned with basic biological terms, solving a biological problem, composition of cells and tissues and various sections like circulation, enzymes and biodiversity. The study of various systems like gaseous exchange, homeostasis, coordination, support and movement and reproduction is also part of the course. The only chapter which can be considered as interrelated with health education is Chapter 8 entitled "Nutrition". This chapter contains basic composition of nutrients; balanced diet and various important aspects of human physical needs (see annex I). It is concluded that out of 18 chapters no information regarding HIV/AIDS is included.

\section{General Science for Grades 9 \& 10:}

General Science is the core subject taught to the students of Arts and Humanities in grades 9 and 10. A single book is used for both the classes half of the chapters are covered in grade 9 while the remaining half is taught in grade 10. Among the total 11 
chapters, two of the chapters are concerned with human health and diseases. Chapter 4 is titled "Human Health" while chapter 5 is named "Diseases: Causes and Prevention" (see annex II). Both of these chapters can be considered as supportive material regarding improving students' health although specific knowledge regarding HIV/AIDS is missing in these sections as well. The rest of the 9 chapters contain technical matter regarding science and technology.

\section{Health \& Physical Education (HPE) for Grades 9 \& 10:}

There are 19 chapters in this subject, 9 for grade 9 and 19 for grade 10. A close analysis of the contents proves that there are 6 chapters $(1,10,12,13,16 \& 17)$ related to health education (Annex III). The rest of the contents are mainly concerned with technical points regarding athletics and sports. Although $30-40 \%$ of the contents of this subject are closely related to health education, no specific titles are included regarding HIV/AIDS. among which only chapter 5 "Ablution \& Physical Cleanliness" can be considered connected to health education but not to HIV/AIDS (Annex IV). Textual analysis of textbooks shows that the contents are insufficient regarding information on HIV/AIDS and contains much specified knowledge according to the subject under study.

\section{Part-II}

To review the impact of insufficient contents regarding HIV/AIDS in school curriculum, the general concept of school students about HIV/AIDS, its mode of transmission and preventive measures was assessed. The data collected in this aspect is analyzed in tables and charts and explained respectively.

The most basic inquiry made in this study was about the students' awareness concerning the term "HIV/ AIDS". The data is summarized in Table 2 below.

Table 2: AWARENESS OF RESPONDENTS REGARDING THE TERM "HIV/ AIDS"

\begin{tabular}{|l|l|l|l|}
\hline Have you ever heard the term HIV/AIDS in your school life? & Freq. & Percent & Cumul. Percent \\
\hline YES & 109 & 72.7 & 72.7 \\
\hline NO & 41 & 27.3 & 100.0 \\
\hline Total & 150 & 100.0 & \\
\hline
\end{tabular}

Source: Field Data

\section{Islamic Education (Compulsory) for Grades 9 \& 10:}

This subject is divided into three parts, a total of 17 lessons. Part-I has 7 lessons and all of the chapters contain Quranic Verses and their Urdu translation. Part-II contains a single chapter having Ahadith and its Urdu translation and explanation. In Part-III various religious concepts has been described and interpreted. This part has 9 chapters
Explanation: The analyzed data shows that majority of the respondents i.e. 109 out of $150(72.7 \%)$ were of the opinion that this term is known to them. The data is presented below as pie chart (fig.1). 


\section{FIG. 1 AWARENESS OF THE RESPONDENTS REGARDING THE TERM "HIV/ AIDS"}

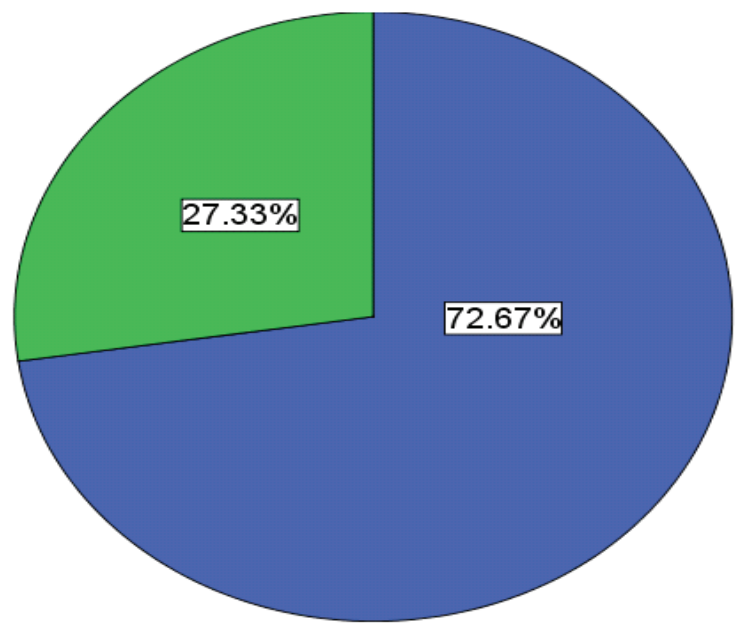

$\square$ YES

$\square \mathrm{NO}$

The next inquiry made in this research study was to assess the knowledge of respondents about the mode of transmission of HIV/ AIDS (Table- 03).
Explanation: The collected data reveals that majority of the school students i.e. $87.3 \%$ (131 out of 150) are unaware about the rout of transmission of HIV/ AIDS (Fig. 02).

Table 3: AWARENESS OF STUDENTS REGARDING MODE OF TRANSMISSION OF HIV/AIDS

\begin{tabular}{|l|l|l|l|}
\hline What is the mode of transmission of HIV/ AIDS? & Freq. & Percent & Cumul. Percent \\
\hline Through infected blood, sharps & 4 & 2.7 & 2.7 \\
\hline Through food and water & 10 & 6.7 & 9.3 \\
\hline Unprotected sex & 5 & 3.3 & 12.7 \\
\hline Don' t Know & 131 & 87.3 & 100.0 \\
\hline Total & 150 & 100.0 & \\
\hline
\end{tabular}

Source: Field Data

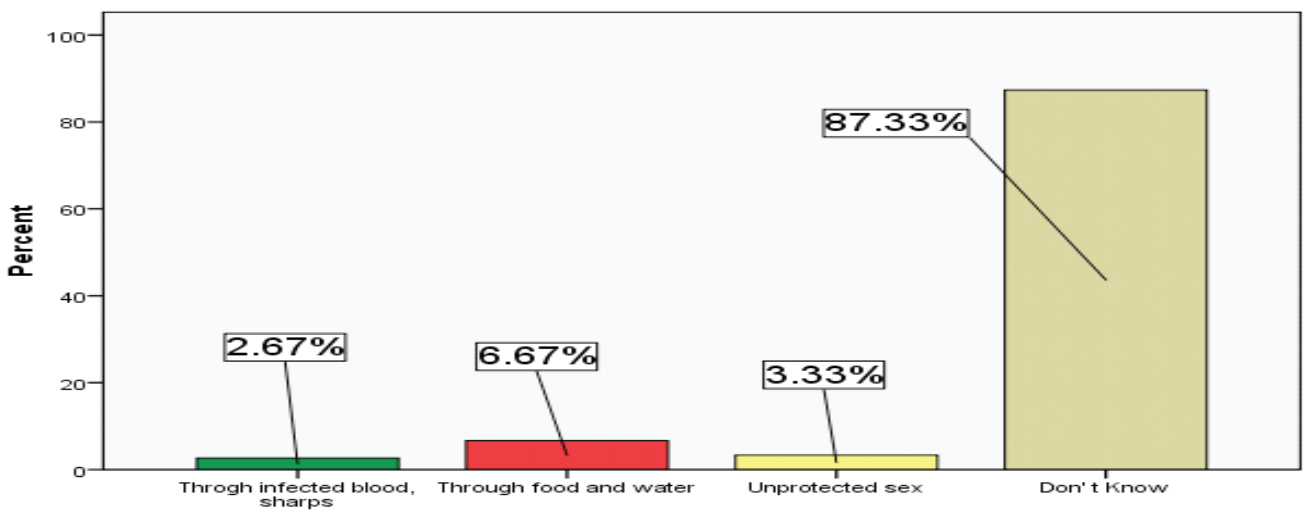

FIG. 2 AWARENESS OF STUDENTS REGARDING MODE OF TRANSMISSION OF HIVI AIDS 
During the course of research all the respondents were asked about the preventive measures against HIV/AIDS (Table 4).
All the respondents were asked that whether contents on HIV be included in school syllabus (Table 5).

Table 4: AWARENESS OF RESPONDENTS ABOUT PREVENTION OF HIV/ AIDS

\begin{tabular}{|l|l|l|l|}
\hline How HIV/AIDS can be prevented from transmission? & Freq. & Percent & Cumul. Percent \\
\hline Protected Sexual Behavior & 3 & 2.0 & 2.0 \\
\hline Avoiding infected blood, sharps & 6 & 4.0 & 6.0 \\
\hline Avoiding food used by HIV Patient & 5 & 3.3 & 9.3 \\
\hline Don' t Know & 136 & 90.7 & 100.0 \\
\hline Total & 150 & 100.0 & \\
\hline
\end{tabular}

Source: Field Data

Explanation: The collected data is analyzed and tabulated which proves that majority of the respondents i.e.136 out of 150 $(90.7 \%)$ are unable to recognize the basic prevention against HIV/ AIDS (Fig. 3).
Explanation: Majority of the respondents agreed that contents on HIV should be introduced in the school curriculum (129 out of 150 i.e. $86 \%$ ). Fig. 4 illustrates the data.

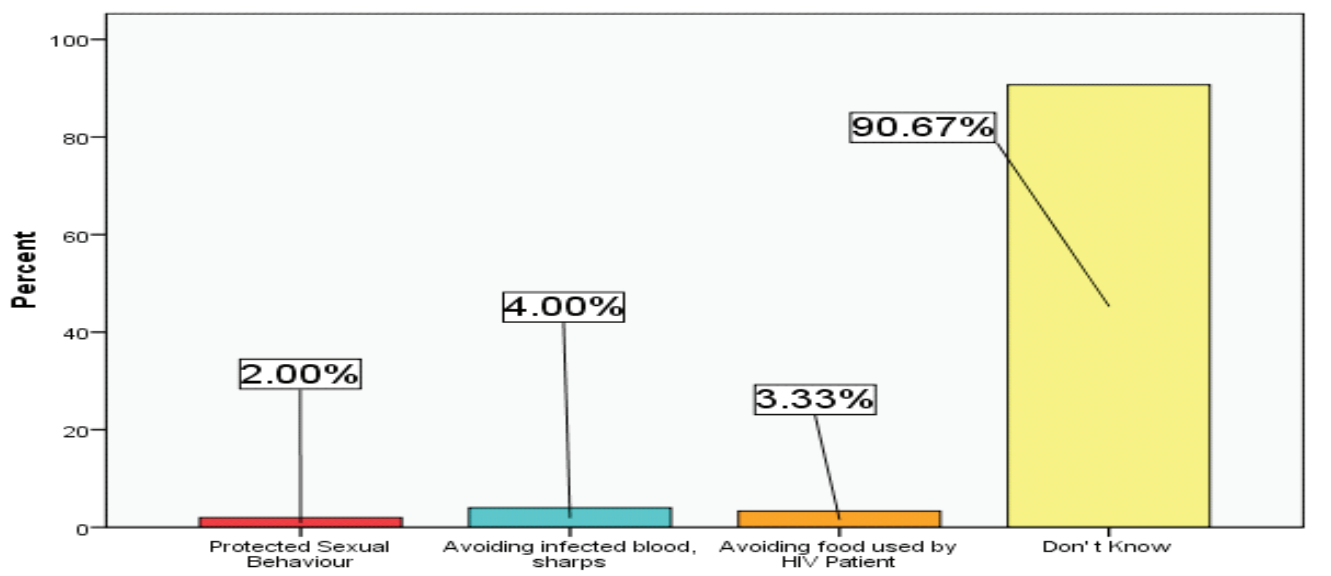

FIG. 3 AWARENESS OF RESPONDENTS ABOUT PREVENTION OF HIVI AIDS

Table 5: SUGGESTION OF RESPONDENTS REGARDING INCLUSION OF HIV/AIDS CONTENTS IN SCHOOL SYLLABUS

\begin{tabular}{|l|l|l|l|}
\hline $\begin{array}{l}\text { Should contents on HIV/AIDS be included in school } \\
\text { syllabus? }\end{array}$ & Freq. & Percent & Cumul. Percent \\
\hline YES & 129 & 86.0 & 86.0 \\
\hline NO & 3 & 2.0 & 88.0 \\
\hline Don't know & 18 & 12.0 & 100.0 \\
\hline Total & 150 & 100.0 & \\
\hline
\end{tabular}

Source: Field Data 


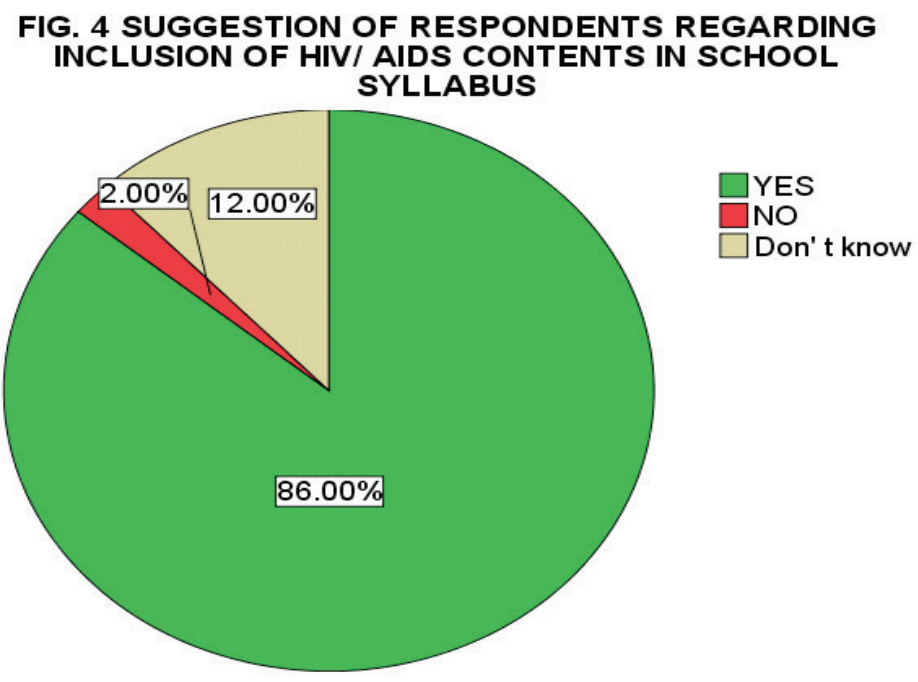

Beside the inquiry on inclusion of HIV contents, the students were also asked about the addition of contents regarding other infectious diseases in the curriculum. The collected facts are analyzed in Table 6 below.
Explanation: The data shows that majority of the respondents i.e. 124 out of 150 $(82.7 \%)$ wishes to include contents regarding infectious diseases in school syllabus (Fig. 5).

Table 6: SUGGESTION OF STUDENTS ABOUT INCLUSION OF CONTENTS ON INFECTIOUS DISEASES IN CURRICULUM

\begin{tabular}{|l|l|l|l|}
\hline $\begin{array}{l}\text { Should the contents on other infectious diseases } \\
\text { be included in the current school curriculum? }\end{array}$ & Frequency & Percent & Cumul.Percent \\
\hline YES & 124 & 82.7 & 82.7 \\
\hline NO & 13 & 8.7 & 91.3 \\
\hline DON'T KNOW & 13 & 8.7 & 100.0 \\
\hline Total & 150 & 100.0 & \\
\hline
\end{tabular}

Source: Field Data

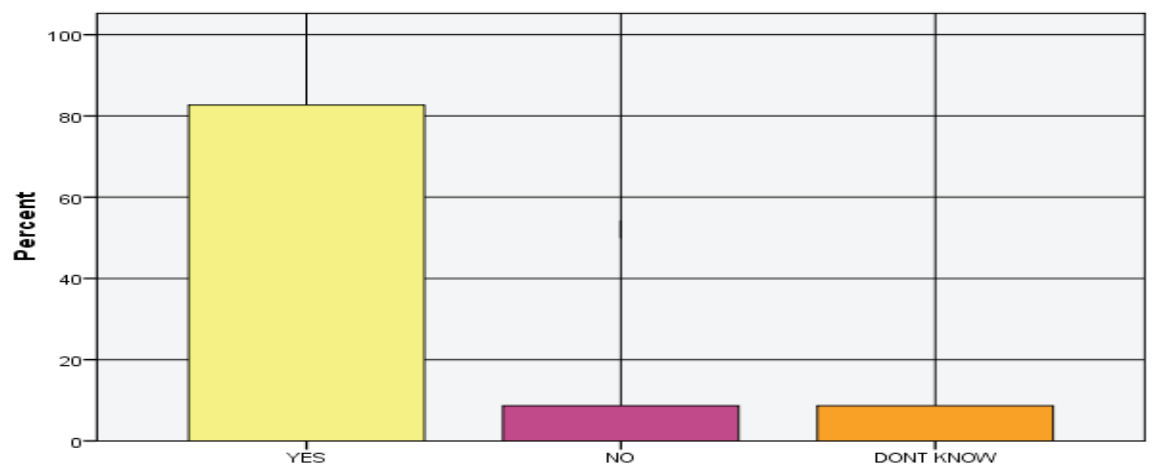

FIG. 5 SUGGESTION OF STUDENTS ABOUT INCLUSION OF CONTENTS ON OTHER INFECTIOUS DISEASES IN CURRICULUM 


\section{Conclusion}

Closing the discussion, it is evident that school syllabus and books are incomplete in respect to the contents on HIV/AIDS. Due to this, students of the government schools are unaware about the basic transmission and prevention of HIV. The major focus of the books is on issues mostly related to economy, sciences as well as issues related to the outcome of the education system. However, the major focus i.e. health and particularly HIV/AIDS is missing in the discussion of the text of the selected books.

\section{Recommendations}

- Health Education on HIV/AIDS must be offered to all the students in government schools equally via a comprehensive course outline.

- Public Health Department ought to be involved in designing a uniform health education curriculum for school. This syllabus must contains stuff on infectious diseases especially HIV/AIDS.

Annex I

Biology for Class 09 \& 10-Book Content Titles

\begin{tabular}{|c|c|}
\hline $\begin{array}{l}\text { Book Name } \\
\text { and Class }\end{array}$ & Chapter Titles \\
\hline $\begin{array}{l}\text { Biology for } \\
\text { Grade } 9\end{array}$ & $\begin{array}{ll}\text { - } & \text { Introduction to Biology } \\
\text { - } & \text { Solving a biological } \\
& \text { Problem } \\
\text { - } & \text { Biodiversity } \\
\text { - } & \text { Cells and Tissues } \\
\text { - } & \text { Cell Cycle } \\
\text { - } & \text { Bio- enzymes } \\
\text { - } & \text { Nutrition } \\
\text { - } & \text { Transport }\end{array}$ \\
\hline $\begin{array}{l}\text { Biology for } \\
\text { Grade } 10\end{array}$ & $\begin{array}{l}\text { - } \text { Gaseous Exchange } \\
\text { - Homeostasis } \\
\text { - } \text { Coordination } \\
\text { - } \text { Support and Movement } \\
\text { - } \text { Inheritance } \\
\text { - } \text { Man and His Environment } \\
\text { - } \text { Piotechnology } \\
\text { Pharmacology }\end{array}$ \\
\hline
\end{tabular}

\section{Annex II}

General Science for Grade 9 \& 10 - Book

Content Titles

\begin{tabular}{|c|c|}
\hline $\begin{array}{l}\text { Book Name } \\
\text { and Class }\end{array}$ & Chapter Titles \\
\hline $\begin{array}{l}\text { General } \\
\text { Science for } \\
\text { Grade } 9 \text { \& } 10\end{array}$ & $\begin{array}{l}\text { - Introduction (The Role of } \\
\text { - Science) } \\
\text { - } \text { Our Life and Chemistry } \\
\text { Biochemistry and } \\
\text { Biotechnology } \\
\text { - Man and his Health } \\
\text { Diseases- Causes and } \\
\text { Prevention } \\
\text { - Environment and Natural } \\
\text { - Resources } \\
\text { - Energy } \\
\text { - Electricity } \\
\text { - Slectronics } \\
\text { - Science and Technology } \\
\text { Space Research and } \\
\text { Pakistan Atomic Energy } \\
\text { Plan }\end{array}$ \\
\hline
\end{tabular}

\section{Annex III}

Health \& Physical Education for Grade 9 \& 10 Book Content Titles

\begin{tabular}{|c|c|}
\hline $\begin{array}{l}\text { Book Name } \\
\text { and Class }\end{array}$ & Chapter Titles \\
\hline $\begin{array}{l}\text { Health \& } \\
\text { Physical } \\
\text { Education } \\
\text { for Grade } 9\end{array}$ & $\begin{array}{ll}\text { - } & \text { Introduction to Physical } \\
& \text { Education } \\
\text { - } & \text { Physical Movements } \\
\text { - } & \text { Gymnastics and Physical } \\
\text { Activity } \\
\text { - Posture and Posture } \\
\text { Imbalance } \\
\text { - Massage } \\
\text { - Physical Fitness- } \\
\text { Characteristics of a Good } \\
\text { - } \text { Tthlete } \\
\text { - Sournament System } \\
\text { - } \text { Athletics Rules }\end{array}$ \\
\hline
\end{tabular}




\begin{tabular}{|l|ll|}
\hline & - & Importance of Physical \\
& Education \\
& Recreation and Small Area \\
& Games \\
& Definition of Health, \\
& Community Health and its \\
& Importance \\
Health \& & Health Prevention \\
Physical & Training: Physical \\
Education & Exercises for correcting \\
for Grade 10 & Posture \\
& Joints and Muscles \\
& Healthy School \\
& Environment \& Infectious \\
& diseases \\
& Our Food \\
& Sports Rules \\
& Athletics Rules \\
\hline
\end{tabular}

\section{Annex IV}

Islamic Education (Compulsory) for Grade 9 \& 10-Book Content Titles

\begin{tabular}{|c|c|}
\hline $\begin{array}{l}\text { Book Name } \\
\text { and Class }\end{array}$ & Chapter Titles \\
\hline $\begin{array}{l}\text { Islamic } \\
\text { Education } \\
\text { (Compulsory) } \\
\text { for Class } 9 \\
\& 10\end{array}$ & $\begin{array}{l}\text { Part-I } \\
\text { Initial } 07 \text { chapters contain } \\
\text { Quranic Verses \& Translation } \\
\text { Part-II } \\
\text { Chapter 08- Ahadith \& } \\
\text { Translation } \\
\text { Part-III } \\
\text { - Introduction to Quran } \\
\text { - Following Allah \& His } \\
\text { Prophet (PBUH) } \\
\text { - Knowledge and its } \\
\text { Importance } \\
\text { - Zakat } \\
\text { - Physical Cleanliness } \\
\text { Patience and Our } \\
\text { individual \& Collective } \\
\text { Life } \\
\text { - Importance of Daily Life } \\
\text { - Migration and Jihad } \\
\text { - Human Rights }\end{array}$ \\
\hline
\end{tabular}

\section{References}

1. MONASCH R, MAHY M (2006) Young people: the centre of the HIV epidemic. World Health Organ Tech Rep Ser.;938:1541.
2. UNITED NATIONS POPULATION FUND, HIV/AIDS BRANCH (2008) Inter-Agency Task Team on HIV and Young People: overview of HIV interventions for young people. New York, NY: p. 8. (http://www.unfpa.org/ hiv/iatt/docs/overview.pdf, accessed on 10 January 2015).

3. ANDERSON J E, KANN L, HOLTZMAN D, ARDAY S, TRUMAN B, KOLBE L (1990). HIV/AIDS knowledge and sexual behavior among high school students. Fam Plann Perspect:;22:252-5.

4. THOMSON C, CURRIE C, TODD J, ELTON R (1999) Changes in HIV/AIDS education, knowledge and attitudes among Scottish 15-16 year olds, 1990-1994: findings from the WHO: Health Behavior in School-aged Children Study (HBSC) Health Educ Res.;14:357-70.

5. POMMIER J, GUEVEL M R, JOURDAN D (2010) Evaluation of health promotion in schools: a realistic evaluation approach using mixed methods. BMC Public Health, 10 (43), 1- 12. doi:10.1186/1471-2458-10-43.

6. BOLER T, AGGLETON P (2004) Life skills-based education for hiv prevention: a critical analysis. Policy \& Research; (3).

7. OSHI D C, NAKALEMA S, OSHI L L (2005) Cultural and social aspects of HIV/ AIDS sex education in secondary schools in Nigeria. Journal of Biosocial Science, 37(2), 175-83.

8. PAUL P (2012) Quality assurance in the teaching and learning of HIV and AIDS in primary schools in Zimbabwe: Zimbabwe Open University.

9. UNESCO (2002) The impact of HIV/AIDS on education and institutionalizing preventive education. International Institute of Educational Planning: UNESCO; ISBN:928031221-9.

10. UNAIDS (2001) Children and Young People in a World of AIDS. Geneva: UNAIDS, 2001.

11. KIRBY D, LARIS B A, ROLLERI L (2005) Impact of sex and HIV education programs 
on sexual behaviors of youth in developing and developed countries. Research Triangle Park, NC: Family Health International.

12. ISHIKAWA N, PRIDMORE P, CARRHILL R, CHAIMUANGDEE K (2011) The attitudes of primary schoolchildren in
Northern Thailand towards their peers who are affected by HIV and AIDS.

13. AIDS CARE (2008) 23(2): 237-244. doi: 1 0.1080/09540121.2010.507737 Elementary \& Secondary Education Department. (2008) Annual Statistical Report2007-08. Govt. of NWFP District Swat. 